\title{
Jonathan Edwards and a reformational view of the purpose of education
}

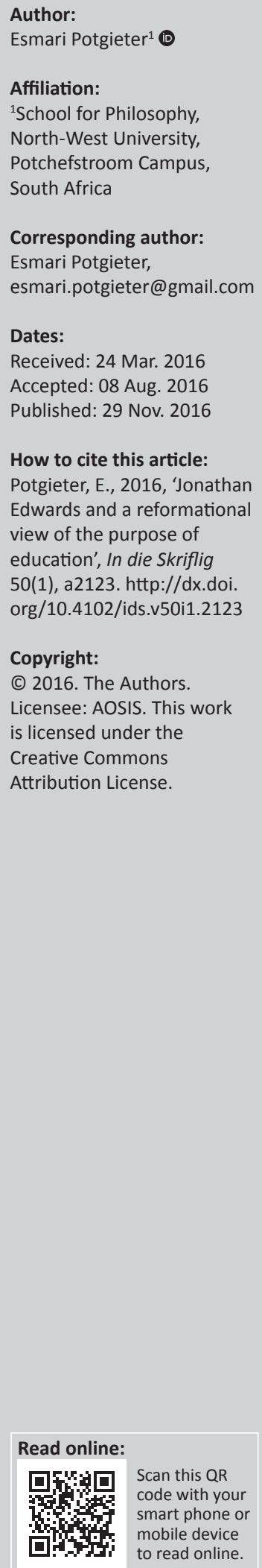

The contemporary quest for spirituality (or spiritual 'connection') in formal education can be linked to the question what education is for. The present article is concerned with contributing to a reformational approach to the question of the purpose of education, with specific reference to spirituality. From a reformational perspective, spirituality should be understood within the framework of the relation between God and his creation. In this article I turn to the thought of Jonathan Edwards (1703-1758), a philosopher-theologian who was convinced that the world exists to communicate the glory of God. This conception of the relation between God and creation gave rise to three recurrent themes in Edwards' philosophy which, I will argue, may be conducive to a reformational understanding of the purpose of education. These themes may provide us with ways of conceptualising various types of spiritual 'connection' in school education. The three philosophical themes are: knowledge as the true perception of relations; human beings as creation's consciousness; and sound morality as arising from true perception. Provided that certain weak points (from a reformational philosophical point of view) are adjusted, these themes can be fruitfully applied to the question of the purpose of education.

\section{Introduction}

Increasingly calls are being made for the integration of spirituality into formal education (Carr \& Haldane 2003; Palmer 1993; Vokey 2003; Wane \& Ritskes 2011). It seems that this is a reflection of a wider turn to spirituality in public life and in academia, which Kourie (2006:35) sees as 'an indication of a deep-felt desire within the hearts of women and men to find unity and wholeness, both individually and in society'.

There remains within the academic discourse a lack of clearly defined criteria for the investigation and evaluation of spirituality (Anderson \& Grice 2014:15; Botha 2006:95). The same can be said of the discourse regarding spirituality in formal education (cf. Dayton 2015:1). However, discussions in this area seem to have a specific emphasis in common. The emphasis here is on spirituality as 'connection', whether a 'deep connection' between the teacher, the learner and the object(s) of study (Jones 2005:6; cf. Palmer 1993:88-89), a connection between the learner and the world (Dayton, 2015:2; Wane \& Ritskes 2011:xvi) or a connection between knowledge and moral behaviour (Culham 2015:309). As shown by these examples, there is no clear consensus regarding the kind of connection that should be striven for in education. Vokey (2003:174) seems to be correct in suggesting that approaches to spirituality in education are as varied as views of 'what it is that we are currently alienated from'.

The search for spirituality in education then can to a large extent be understood as a reaction to perceived alienation or 'disconnection' in contemporary education (cf. Palmer 1993:x). More fundamentally, the search for spirituality has to do with the question of what the purpose of education is. This is illustrated by Carr and Haldane (2003:2) when they explain their and their co-workers' interest in the relation between education and spirituality as being an interest in 'the question of what schooling might aim for in the field of personal formation beyond the acquisition of transferable skills and broad social values'.

On the negative side, the perceived lack of spirituality in contemporary education is often attributed to wrong or narrow conceptions of the purpose of education. Palmer (1993:7-8), for instance interprets the disconnection in education as arising from the motives which have underlain the modern search for knowledge, namely those of curiosity and control. Both these motives create distance between the learner and his or her world. Kawano (2011:106) again, regards the 
threat to 'the development of a sense of interconnectedness' in schooling as coming from a worldwide prioritisation of economic goals. ${ }^{1}$

Acknowledging that there is no religiously neutral view of spirituality or of the purpose of education, the present article is concerned with contributing to a Christian, specifically a reformational ${ }^{2}$ approach to this issue. Van der Walt et al. (2008:13) have highlighted the contemporary need for working towards a better understanding of biblical spirituality and its place in education. The question that will specifically be dealt with in this article is: How can one understand the purpose of school education in such a way as to do justice to the contemporary search for spirituality (or spiritual connection) in education?

From a reformational perspective, spirituality should be understood within the framework of the relation between God and his creation. ${ }^{3}$ In this article I will turn to the works of the philosopher-theologian Jonathan Edwards (17031758), exploring his understanding of this relation. Edwards' worldview and philosophy ${ }^{4}$ will first briefly be presented with the focus on his understanding of the relation between God and created reality. This will be followed by an exploration of three recurrent philosophical themes in Edwards' writings which, as I will argue, have arisen from his understanding of the relation between God and creation. Thirdly, I will suggest applications of these three themes to the question of the purpose of school education, paying special attention to the matter of spirituality in education. A few of Edwards' own educational ideas will be integrated into the discussion. ${ }^{5}$

\section{Palmer's and Kawano's somewhat different diagnoses are in tune with the observation of Goheen (2002) that, whereas the modern ideal of progress through science and reason had formerly driven western education, it has now been replaced by economistic and consumerist ideals (cf. Postman 1996:19-58). Arguably, economism and consumerism are simply new appearances of the ideal or motive of 'control' (Palmer 1993:7-8). According to Fowler (1990:70) this ideal (which he terms the ideal of 'autonomous human mastery') is shaping postmodern education as much as it has shaped modern education.}

2.An approach can be described as 'reformational' if it takes God's revelation in the Bible as starting point, recognising that it 'touches the heart, the religious root, of humankind and therefore cannot remain restricted to church life and religion in its narrow sense, but must come to expression in all walks of life' (Strauss 2012:1). Reformational philosophy with Herman Dooyeweerd (1894-1977) and D.H. Th Vollenhoven (1892-1978), generally regarded as its foundational figures, accordingly seeks to understand all of reality in the light of the major motives of Scripture, namely creation, fall and redemption (Wolters 2005).

3. I will deliberately use the term relation (instead of connection) when what is in view is specifically an understanding of spiritual 'connection' that is informed by the belief in a personal God.

Reformational anthropology does not allow for a view of spirituality in which the latter is seen as an 'add-on', or a donum superadditum, to human life. Rather, human life at its very centre is seen as being related to God ('religious'). The religious centre of human life, which may be called the 'heart' (Prov 4:23) or, religious centre of human life, which may be called the 'heart' (Prov 4:23) or, alternatively, the 'spirit' or the 'soul' (Vollenhoven, 2005:61), is directed either
towards God in obedience to his covenant call, or away from him in disobedience (Vollenhoven, 2005:78). I will return to this point in the last section, when evaluating Edwards' thought.

4.Edwards was first and foremost not a philosopher, but a pastor and theologian When referring to his worldview, I have in mind the pre-scientific views and reflections encountered in writings such as his diary, his letters and some of his notebook entries. Yet Edwards has also become known (especially since the publication of his biography by Perry Miller in 1949) for the philosophical views and arguments expressed especially in some of his larger works. These bear witness to arguments expressed especially in some of his larger works. These bear witness to mind who relentlessly sought, in the face of Enlightenment philosophy, to understand the universe as a place where 'everything is related because everythin between theology, worldview and philosophy are not always easy to trace.
Lastly, a preliminary evaluation of the potential of Edwards' thought will be made from a reformational philosophical point of view. It is hoped that the explored themes may prove conducive to a reformational understanding of the purpose of education in which biblical spirituality is well accounted for.

\section{Created reality as related to God}

Edwards, a Congregationalist pastor-theologian whose preaching would stir New England's First Great Awakening (1730s to 1740s), had himself experienced a spiritual awakening at the age of seventeen. Upon reading the words of 1 Timothy 1:17, 'Now unto the King eternal, immortal, invisible, the only wise God, be honour and glory forever and ever, Amen', Edwards felt a 'sense of the glory of the divine being' which 'gradually increased', so that ' $[t]$ he appearance of everything was altered: there seemed to be, as it were, a calm, sweet cast, or appearance of divine glory, in almost everything' (Edwards 1998:792-793). This event, as an expansive body of sermons, essays and notebook entries indicates, ${ }^{6}$ would subsequently shape his whole life and thought (cf. Noll 1995:145).

Edwards would never explain his sense of God's glory 'in almost everything' as the merely subjective act of an impassioned imagination. In one of his last completed works, Dissertation concerning the end for which God created the world, he provides a firm ontological basis for the human experience of the glory of God in creation. Creation is here described as God's purposeful communication of his glory, both through creation, as it came into existence, and to creation, as it already exists (Edwards 1989:432-437, 441-442). Creation is therefore related to God as a purposeful act is related to its subject. Edwards goes as far as to say that the universe may be regarded as 'created out of nothing every moment' (Edwards 1980c:241).

Given the prevalence of mechanistic science and philosophy in his time, it is quite understandable that Edwards would see the need for emphasising created reality as an ongoing act of God. The mechanistic conception of nature is that of a 'self-contained and independent reality, a self-inclusive machine running by itself according to abstract, universal laws of nature' (Zakai 2002:19). It is this conception that Edwards was contending against, even while acknowledging and marvelling at new discoveries (such as those made by Newton) of the 'laws of nature'. For Edwards the laws of nature together with all of reality were conceivable only in relation to God. [T]o 'find out the reasons of things in natural philosophy', he (Edwards 1980e:353) insisted, 'is only to find out the proportion of God's acting'. Even 'matter' could be regarded as the immediate exercise of the divine power in a particular way (Edwards 1980b:215; 1980c:235).

The dynamism in Edwards' worldview is teleologically motivated. While natural laws do exist, they exist only to 6. Edwards' (2015) complete work was recently published online by Yale University in seventy-three volumes (see http://edwards.yale.edu). 
serve the purposes of God who, 'in all things, acts as being limited and directed in nothing but his own wisdom' (Edwards 2004:202). From Scripture Edwards found ample evidence that the ultimate purpose with which God has created is to communicate his glory. This 'glory' was understood by Edwards mainly to consist of the knowledge, love and joy that exist between the three Persons of the Trinity (Edwards 1989:432-437, 441-442, 531).

It can be said of Edwards' worldview and ontology that they are saturated with his conception of God's glory (cf. Sairsingh 1986:3). If Edwards has something to offer to our present inquiry, it will be due to the 'dialectical fearlessness' (McClymond \& Reinke 2012) with which he worked out the implications of this worldview and ontology in areas such as epistemology, anthropology and ethics. In the sections to follow, I will turn to Edwards' ideas within these three areas, focusing specifically on three recurrent themes. I take each of these three themes to be to a certain extent, at least, a philosophical outcome of Edwards' view of the world as 'God-related'. This, as I will seek to show, makes them relevant for the present inquiry.

The following three themes will be investigated and applied to the question of the purpose of education (specifically with reference to spirituality), namely knowledge as the true perception of relations; human beings as creation's consciousness; and sound morality as arising from true perception.

\section{Knowledge as the true perception of relations}

Following Locke, Edwards (1980e:347) regards the 'simple ideas' gained by sensory experience as instrumental to all knowledge. However, as argued by Lee (1988:123-125), the relational ontology of Edwards provides him with an escaperoute from Lockean rationalism. In Edwards' own words, knowing truth is to perceive 'the relation between the ideas', while falsehood is 'an inconsistent supposition of relations' (Edwards 1980:340). This should not be taken to mean that one may have a true idea of something and yet fail to see it in its right relation to other things. For Edwards the being of anything is bound up so closely with its relations to other things, that 'if the idea [of it] were perfect, it would be impossible but that all its relations should be perfectly perceived' (1980:340).

How is it possible then for the mind to perceive relations between its ideas? Put differently: How can one perceptively know not only individual things, but also the relations in which these things exist? It is important to observe in this regard that Edwards' concern with relations is at the same time a concern with beauty. Beauty can be said to consist in harmonious relations, often referred to by Edwards (cf. 1980d:305) as consents. In the case of outwardly perceptible beauty, consents consist in equality and proportion (Edwards 1980e:380). There is also beauty in less apparent types of proportion found in things such as justice, order in society, and a life lived wisely (Edwards 1989:568-569). Love is considered by Edwards (1989:564) to be the most beautiful, since it consists of purposeful consent between spiritual beings.

Beauty, or 'excellence' (virtually synonymous terms for Edwards - cf. 1980e:344, 382), is 'what we are more concerned with than anything else' (1980:332). As a result the mind is 'abundantly active'. It is continually bringing 'its ideas into contemplation', and 'ranging and comparing' them 'in reflection and abstraction' (1980:374). In short, the mind is continually relating its ideas, in order that it may know the objects of these ideas and the world itself in their beauty or deformity. It is now possible to explain why Edwards wants the knowledge of relations to be understood as a form of perception. To know things for their beauty or deformity is to know them in 'their relation to our wills, and affections, and interest, as good or evil, important or otherwise, and [in] the respect they bear to our happiness or misery' (Edwards 2000:460). This mode of knowing is referred to by Edwards as 'sensible' knowledge, since like sensory perceptions it is accompanied immediately by pleasure or displeasure. It is to be distinguished from 'speculative' or 'notional' knowledge which does not impact us affectively. Moreover it can and should be the outcome of 'speculative' knowledge. Ultimately, as Edwards (2000:459-460) sees it, 'we are concerned to know nothing on any other account than as it pertains to our affections'.

There is another reason besides its being of an affective nature, that the knowledge of relations can be called 'perception'. As with sensory perception, the knowledge of relations is a response - whether true or false - to realities that exist independently of the mind. Beauty is not a human construct, but is interwoven into a world which exists to communicate the glory of God. All people can appreciate beauty in the harmonious relations which exist, for example in nature and in a just and well-ordered society. The appreciation of these kinds of beauty is due to 'a law of nature, which God has fixed' (Edwards 1989:565). However, since all things are ultimately related to God 'of' whom, 'through' whom and 'to' whom everything exists (1989:551), the ultimate beauty (or deformity) of things can be perceived only when the mind's relating activity is governed by the knowledge of God.

How then is the knowledge of God to be gained? In this regard Edwards still sees no reason to depart from an empiricist understanding (Plantinga 2000:299). Recall that he describes his own conversion as having entailed a 'sense' of God's glory. In his work, Treatise concerning religious affections, he argues that essential to regeneration is 'a new spiritual sense (...) or a principle of new kind of perception or spiritual sensation' (Edwards 1959:205). This sense is called spiritual due to its being given by the Spirit (cf. 1959:198). Through it the glory of God, as revealed in Scripture, ${ }^{7}$ is not simply

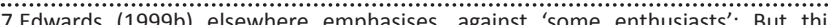
spiritul (ight that I am speaking of, is quite a different thing from inspition: spiritual light that l am speaking of, is quite a different thing from inspiration. it reveals no new doctrine, it suggests no new proposition to the mind, it teaches no new thing of God, or Christ, or another world, not taught in the Bible; but only give a due apprehension of those things that are taught in the Word of God (p. 412). 
known of, but known as if sensibly perceived or 'tasted' (cf. 1959:259-260). Just as tasting something good is accompanied by pleasure, so knowing God's glory through the spiritual sense entails delighting in it (cf. 1959:260; 1994:200).

Two things deserve our notice. Firstly, it should be recognised that Edwards holds firmly to a Calvinistic view of sin and depravity. He understands the noetic effects of sin to be so pervasive that nothing but 'immediate divine assistance' can give to someone 'a sense of spiritual and eternal things' (Edwards 2000:462; cf. Oliphint 2003). Secondly, it should be noticed that the spiritual sense, as understood by Edwards, both 'incorporates and enhances natural modes of perception' (Lane 2004:46). Within those who are endowed with the spiritual sense, the perception of outward beauty may 'enliven (...) a sense of spiritual beauty' (Edwards 1989:565). Then the world can be known and enjoyed for what it truly is: the communication of the glory of God, who is himself the 'foundation and fountain of all being and all beauty' (1989:551).

In this section it was seen that, according to Edwards, knowing things in their right relations requires knowing them in their relation to God's glory. In the following section, it will be shown that there is a logical prerequisite to such knowledge. This prerequisite is that things will be known in their relation to human beings.

\section{Human beings as creation's consciousness}

As far as creation is concerned, Edwards is unashamedly anthropocentric. This is to be expected, given the central place of communication in his worldview. If the world exists to communicate it may as well not exist if there are no conscious receptors of its message (Edwards 1989:431). Thus the position of 'consciousness' is of ontological importance (cf. 1989:432). It is a position which human beings (together with the angels) hold due to their rational, affective and moral capabilities.

This view of the relation between the non-human creation and human beings has profound implications for Edwards' understanding of both. The non-human creation (with the exception of angels) is teleologically subordinated to human beings. It achieves its purpose through serving as the 'house' wherein its human inhabitants may achieve theirs (cf. Edwards 1989:470-471). In their turn humans bring 'the world to a consciousness of its beauty in God' (Lane 2004:68).

Edwards continually marvels at the various ways in which creation serves humanity's best interests. An example of this comes from the famous 'Spider letter' which he wrote to the Royal Society of London, probably hoping for its publication in their scientific paper (Anderson 1980:151). Edwards' (1980a:167) careful observations of the ways in which spiders spin and move along their webs moves him to lyrical praise at 'the exuberant goodness of the Creator, who hath not only provided for all the necessities, but also for the pleasure and recreation of all sorts of creatures'.
Yet although 'recreation' must be one purpose behind this ability of spiders, Edwards believes that an even 'greater end' is their own destruction. Due to reasons connected to their web-spinning habits, large numbers of spiders are annually taken off by the wind and drowned in the ocean. In this, God's wisdom is even further displayed, since 'great inconveniences' to people are thereby prevented (Edwards 1980a:167-168). Clearly, in Edwards' view even a spider's functioning can be comprehended only if perceived within a broader teleological framework, where priority is assigned to human beings.

It is one thing to say that non-human creation serves human needs and convenience. However, Edwards goes further and contends that non-human creation is communication and human beings the conscious receptors of this communication. This relation is implied throughout Edwards' writings. The wonders of creation are meant to display God's 'goodness' and his 'wisdom'. As our example has shown, Edwards sees the non-human creation displaying God's goodness and wisdom especially in the ways that it serves human interests. In the case of the redeemed, or those in '[u]nion with Christ', he (Edwards 1994) states it quite radically:

Every atom in the universe is managed by Christ so as to be most to the advantage of the Christian, every particle of air or every ray of the sun. (p. 184)

The priority that human beings have in Edwards' scheme cannot be interpreted as a licence for doing with creation as we please. Edwards' view of human beings as creation's 'consciousness' prohibits such an interpretation. Humans' ultimate purpose is to perceive the glory of God. This is also where their best interest, or their utmost 'happiness', lies (cf. Edwards 1999a:72). Moreover, it entails great responsibility. It is only through its 'consciousness' that creation can fulfil its ultimate purpose, which is to make known the glory of God.

We now turn to the important question of how, in Edwards' view, human beings are able to fulfil their responsibility as creation's consciousness. Edwards' conception of the spiritual sense is again at play here. It is telling that in the two notebook entries where Edwards refers to human beings as 'consciousness', the emphasis is not on cognitive understanding but on happiness. Happiness is considered by Edwards (1994) as the natural result of understanding God's glory:

An understanding of the perfections of God, merely, cannot be the end of the creation; for [one] had as good not understand it, as see it and not be at all moved with joy at the sight. (p. 200)

Thus, the role of consciousness can be fulfilled only if the understanding of God's glory is coupled with fitting affective response. Understanding and affective response are not polar opposites, but function in union within the mode of knowing that is enabled through the 'spiritual sense', as described in the previous section. This sense is elsewhere described by Edwards (1959:272) as a 'sense of the heart, wherein the mind doesn't only speculate and behold, but relishes and feels'. 
Moreover, as will be expounded on in the following section, it is largely this mode of knowing that will induce a person to act (1959:101).

\section{Sound morality as arising from true perception}

In the discourse on spirituality in education, concerns with the ethical outcomes of education occupy an important place. This merits a brief discussion of Edwards' ethical thought, especially as his ethics is intricately linked to the first two themes discussed above. ${ }^{8}$

Edwards' ethics is the counterpart of his view of human beings as 'consciousness'. Not only are human beings meant to receive the communication of God's glory; they are also meant to respond to this glory by conforming their lives to it. For Edwards moral goodness starts with true perception. The abiding sense of God's glory does not lead to otherworldliness. On the contrary, just as God's love for himself causes him to love creation, being the communication of his glory (Edwards 1989:461-462), so the love of a regenerate person is primarily towards God, and consequently and simultaneously towards all that God has created. Moreover the love which directs a regenerate person towards God and towards creation is the direct operation of God's own love. Edwards is led to this conclusion by his understanding of the work of the Holy Spirit. According to Choi (2010), this understanding helps Edwards in emphasising:

(...) the intimate and direct involvement of God in all aspects of human affairs while eschewing a simple deterministic and heteronomous understanding of divine action. Insofar as the Spirit orients and directs anew the creature's powers of knowing and choosing, the human as moral agent is preserved when made to participate in God's overflowing fullness. (p. 277)

As with true perception, sound morality is understood by Edwards as a gift from God through his Spirit. A person with sound (i.e. Spirit-given) morality is an active agent in God's plan to communicate his glory through creation. In fact, according to Edwards it is only the human being who, of all earthly creation, can 'properly' communicate God's glory. Only he or she is able to know, love and rejoice - those three activities that God's glory mainly consists in (Edwards 1989:441-442).

One realises that for Edwards the perception of things can be true only when they are perceived in their relation to the glory of God. Likewise, he views morality as sound only if in it God is 'the first and the last' (Edwards 1989:560). Edwards' ethical system is laid out in its most complete form in his essay, 'The nature of true virtue', written to accompany 'Dissertation concerning the end for which God created the world'. Here he (1989) engages critically with 'writers on morality' who, while they do not 'wholly exclude' God from their theories, still:

(...) insist on benevolence to the created system in such a manner as would naturally lead one to suppose they look upon that as

8.See Troost (1983) for a defence of the inclusion of philosophical ethics as a core discipline of philosophy. by far the most important and essential thing in their scheme. (pp. 552-553) ${ }^{9}$

To Edwards on the other hand, it is unthinkable that any behaviour can be deemed moral if it does not conform to the purpose for which the universe was made. While recognising the goodness of all human loves, he cannot help but think of them as hopelessly constricted when they are not embedded in the love for God. Again writing in aesthetic language, he compares the 'particular' love which is not part of the love for God to a few notes that make a harmonious tune and yet stand in discord with a whole piece of music (cf. Edwards 1989:540).

Another image that is often employed by Edwards to distinguish between sound and defective morality is that of space versus confinement (Spohn 1981). He describes people who exploit others as having a 'private narrow disposition'. Opposite to these are people with a 'public spirit' which testifies to 'greatness of mind' and 'largeness of heart' (Edwards 2006:317-318). Moral confinement is ultimately self-confinement, where others are loved only as 'appendages and appurtenances to [the] self'. Moral enlargement on the other hand, is the result of loving others (and the world itself) 'as of God, or in God, or some way related to him' (Edwards 2000:533).

\section{An application to the question of the purpose of education}

In his fine thesis on Edwards' educational thought and practice, Stelting (1998) ends with the question: 'What, for Edwards, would have been the whole purpose of education?' He then offers this answer:

When Edwards mounted the pulpit, or approached the lectern, or sat beneath the tree in the churchyard on Sunday afternoons surrounded by children, it was for one purpose. He intended to create a context within which people might truly, fully, and savingly see God; and that God might enter into them, giving them, by apprehension, a truth they could not otherwise know. He wished to teach people to know God as he knew God. (pp. 216-217)

Stelting's observation provides us with a helpful point of departure for the application of Edwards' thought to the question of the purpose of education. I will now make three applications, roughly corresponding to the three themes discussed above. These applications will be focused on school education, and specifically school education that is undertaken from a Christian perspective.

My first application is derived from the first discussed theme, which was termed 'Knowledge as the true perception of relations'. In the execution of this application, the second theme, 'Human beings as creation's consciousness', is also involved. The first application can be summarised as follows: Education should provide a context where learners

9.See Carrington (2008) for an overview of the modern ethical theories that Edwards was contending against. 
may increasingly perceive the world as God-related, and therefore glory-filled.

Stelting's choice of the words 'create a context' is an apt formulation of what education as Edwards saw it, is able to achieve. According to Edwards a true perception of the world is possible only if the world is seen in its relation to the glory of God. Within such perception the manifold relations in the world can also be understood and appreciated, since it is through beautiful creaturely relations that the glory of God is communicated. Such perception, however, is possible only through the 'spiritual sense' through which the glory of God is known as if sensibly perceived.

Although Edwards views the spiritual sense as the direct outcome of the work of the Spirit, he also believes that God, in letting this light into the soul, deals with the human being according to his or her 'nature', keeping the 'natural faculties' active in the process (Edwards 1999b:416). Moreover the spiritual sense incorporates and enhances the working of the five senses and of the mind as a whole (cf. 1999b:415). It follows that education can and should provide a context for spiritual perception, that is, for true perception of the world in its relation to God. Not only should it provide a possible context for the regenerative work of the Spirit in bestowing spiritual perception, but also (and in the case of the school, I would say, especially) a context for the increasing exercise of spiritual perception.

Before continuing to a second application, it is worthwhile to pause and consider how a school may provide a context for the increasing perception of the world in its relation to God. While the importance of sensory experience in education should be recognised (Adams 1991), sensory experiences by themselves do not guarantee that ideas will be truthfully related. Edwards would agree with Du Plooy et al. (1982:53-55 $)^{10}$ when they remind us that children need to be guided in their natural search for meaning. While the world is full of meaning - since it exists to communicate the glory of God - this meaning can only be realised through the world's human 'consciousness'. Thus learners need to be helped in 'interpreting' their sensory experiences. This help should come from teachers who themselves are able to perceive creation in its relation to the glory of God.

In view of this Edwards would recommend a dialogic style of education. This can be gathered from a letter written during his employment as missionary educator of Indian children at Stockbridge. He writes of his wish that not only 'words', but 'things' will be 'in a familiar manner, opened to the child's understanding'. A 'familiar manner' entails conversation with the teacher asking questions and encouraging the child to 'speak freely' and ask his own questions 'for the resolution of his own doubts' (Edwards 1998:408). Teaching should venture beyond the transferring of facts to the stimulation and truthful answering of questions regarding the unity and the meaning of what is learned. For this, both competency in theorists C.K. Oberholzer and P. van Zyl. the teacher and trusting relationships between the teacher and his or her learners, are imperative.

Now for a second application which is derived from the second theme, 'Human beings as creation's consciousness'. This application can perhaps be understood as a necessary component of the first application. It can be stated as follows: Education should guide learners to come to know the world as made for them, and themselves as made for it.

The words 'made for' may indeed be essential in helping learners experience connection with the world they are getting to know. Since this connection is given by God and has the purpose of making his glory known, one may truly speak of it as a spiritual connection. This connection (or relation) is aptly described by Fowler (1991):

We belong to earth; this is our home. At the same time this earthly home is not a place at a distance from God. It is the sphere of our fellowship with God who walks this earth with us, revealing himself throughout our earthly life. (p. 18)

In their relation with the rest of creation, human beings are responsible not only to creation, but ultimately to God. It is a relation in which, according to Edwards, they have the position of 'consciousness'. This has profound implications for education. The human responsibility towards the world consists neither in controlling (cf. Palmer 1993:7-8), nor in consuming it (cf. Goheen, 2000:45-47). At the same time it does not end with a concern for preserving it or ensuring its sustainability. Whereas educational thought that centres on sustainability tends to advocate the development of 'ecological' or 'systems' thinking through schooling (cf. Sterling 2001:52; 2008), Edwards would also insist on asking the question: What is the system for? This question is implied in his (Edwards 1994) response to the supposed allegation that Christian 'devotion' makes on less 'useful' to the world:

[This is] the same thing as to say that the world was made that the parts of it might be mutually useful to each other; that is, that the world was made to have all the parts of it nicely hanging together, and sweetly harmonising and corresponding: that is that the world might be a nicely contrived world; that is, that the world was nicely contrived for nothing at all! (pp. 189-190)

If human beings are indeed the consciousness of creation as Edwards understood it, then education should develop awareness with learners that they are not free to choose the meaning of the world and of their own place in it. They should continually be reminded that the relation between themselves and the world is there to serve an ultimate purpose. This purpose is that the glory of God may be known. Learners should come to see themselves, moreover, as having a pivotal role in this regard.

The third application pertains to the response that is required of human beings, if they are to be active agents in the communication of the glory of God. This application is derived from the third theme, 'Sound morality as arising from true perception', and can be stated as follows: Education should promote moral behaviour as a response to true perception. 
The idea that behaviour arises from 'inward thoughts' or worldviews is criticised by Wolterstorff (2002:82). He is concerned that an 'inward' emphasis has led to education that does not impact learners' daily lives. Edwards on the other hand, would attribute a lack of impact not to the emphasis on thoughts, but to the emphasis on a type of thought which he terms 'notional understanding' (Edwards 1959:272). As already mentioned, although notional understanding is necessary, it only impacts behaviour in so far as it results in 'sensible' understanding, or the 'sense of the heart'. When things are known with the 'sense of the heart', they are known in 'their relation to our wills, and affections, and interest' (Edwards 2000:460).

Of course understanding through the 'sense of the heart' can be misguided. After all, our 'wills, and affections, and interest' can be, to use Edwards' language, 'constricted'. What is required for moral goodness is not only sensible understanding, or perception, but true perception, informed by the sensible understanding of Gods glory. I would suggest that it is through promoting true perception that a school can promote morally sound behaviour. This approach can have the advantage of keeping intact the cognitive focus ${ }^{11}$ of the school, while fostering connection between knowledge and morality.

The third application can therefore be taken as an extension of the first, with the school's task of providing a context for true perception now focused on the perception of deliberate human conduct. As Edwards would remind us, a true perception of human actions includes affectively knowing them in their moral goodness or evil. Again sensory encounters and interpretive discussions may serve to provide a context for such perception.

\section{A preliminary evaluation from a reformational philosophical perspective}

It lies outside the scope of this article to give a comprehensive evaluation of Edwards' philosophical thought from a reformational philosophical point of view. For the present I leave largely untouched, for instance the possible concern that Edwards was guilty of 'synthesis thinking', incorporating biblical concepts with ideas from non-biblical origins such as Platonism and Scottish realism (cf. Runner 1970:82). ${ }^{12}$ My main reason for refraining from such an evaluation is the

\footnotetext{
11.From a reformational philosophical point of view, with its emphasis on sphere sovereignty, it is important to acknowledge that the role (also the educational role)
sover of the school is limited. It is normally agreed that the school's primary role, which it is especially equipped for, is the development of the cognitive or intellectual aspect of human functioning (cf. Du Plooy et al. 1982:149). Fowler (1987:13), for instance specifies that formal education should contribute to growth towards fullness of humanity through developing understanding of how creation function [own emphasis]. They (1982:149-150) and Fowler (1990:75-80) would agree however, that the school should promote cognitive development in ways that will, however, that the school should promote cognitive development in ways that will, at the same time, involve and enhance other aspects of human functioning. Based on Edwards' work, it might be suggested that this can be done through helping them know things in ways that involve the affections.

12.Rooy (1965:302) argues that Runner is mistaken in associating Edwards' thought with Platonism. He suggests that Edwards' conceptions of the relation, and even the similarities, between God and humankind is rooted in his understanding of redemption in Christ (1965). For a similar argument, see Schultz (2006:254).
}

manifest lack of scholarly consensus regarding this issue. To what extent Edwards was in fact influenced by classical and modern philosophies, and which philosophies influenced him most strongly, are still matters of debate (Freeberg 1999:202-205; Louie 2007:62-63).

For the present, two matters will briefly be considered, as they pertain especially to a biblical understanding of spirituality and its place in education.

Firstly, there is the question of whether Edwards' concept of the 'spiritual sense' can further a biblical understanding of spirituality and of its place in education. It is clear that for Edwards the 'spiritual sense' is present solely where there is true faith. However, if the 'spiritual sense' amounts to a 'sixth sense' (cf. Lane 2004), there is reason for caution. We are reminded by reformational authors (cf., for instance Wolters 2005:71-72) that salvation and regeneration do not entail the addition of a spiritual dimension as a donum superadditum. Rather in salvation and regeneration the spiritual (or religious) dimension, which is already present in and central to every human being's life, is restored and redirected. One may speak also of a redirection of the heart as the religious centre of the self which directs all aspects of life.

Edwards arguably sees too much discontinuity between life before and life after regeneration (Ortlund 2014:48). He describes the work of the Spirit in regeneration as 'entirely above nature, altogether of a different kind that men find within themselves by nature' (Edward 1959:205). Against this it should be emphasised that regeneration is restorative. The 'sense of the heart' after regeneration can only be new in the sense that it is a 'restored' sense.

This is not to deny that we can learn from Edwards' conception of the spiritual sense as essential to regenerated (restored) human life. If Stelting (1998:217) is right, Edwards' view of the spiritual sense can encourage the creation of educational contexts for the increasing perception of the glory of God. A school, as remarked often by reformational philosophers, needs not take up the role of a family or a church in order to be spiritual in its purpose. It needs not adopt the aim of transferring doctrines of faith. It should, however, serve as a place where learners can increasingly come to know creation as the ongoing display of the glory of God. I have given indications as to how this might be achieved in the previous section.

If Edwards' concept of the spiritual sense is, as I have argued, conducive to a reformational understanding of the purpose of education (i.e. provided the excessive discontinuity between 'natural' and 'renewed' life is adjusted), it still remains to be determined how conducive Edwards' view of the object of the spiritual sense might be. This is my second point of evaluation. The object of the spiritual sense is the glory of God, or as Edwards often puts it, God's beauty. This glory or beauty is harmoniously communicated through Scripture and through creation. The communication of it 
reaches its culmination in God's redemption of the world through Jesus Christ (cf. Gibson 2008:65-75).

We can learn from Edwards as he emphasises a truth which even reformational philosophy, with its emphasis on the creation order and creational laws, does not always fully account for. This truth is that creation is God's ongoing communication of his glory. While learners should be taught to understand the "particular laws of nature with respect to particular creatures' (Edwards 2004:205), they should also be taught to trace how these laws serve the ultimate purpose for which the world was made, which is that God's glory may be communicated. Yet while we can learn from Edwards' teleological emphasis on creation, we should reject the idealist and world-negating directions in which this emphasis often led him (cf. Rupp 1969). If creation can be understood as the 'communication' of God's glory, then this communication should be understood as encompassing all aspects of created reality in their own significant ways. This will withhold us from elevating certain aspects of creation above others, and instead embolden us to look for the glory of God as he displays it in all of creation.

In the same way the human role of being creation's 'consciousness' will also be seen as embracing all aspects. Van der Stelt (2005:55) points us in this direction when he calls for a more comprehensive and more biblical understanding of 'knowing', as 'being aware of, attuned to, looking for, relying upon, responding to, rejoicing in, and giving expression to God's will for all created reality'. In the work of Edwards such a comprehensive understanding of knowledge is sometimes implied, but not fully developed.

\section{Conclusion}

In this article three philosophical themes in the thought of Jonathan Edwards were explored and applied to the question of the purpose of education. The present search for spiritual 'connection' in education is related to the question of what the purpose of education should be. It was suggested that Edwards' thought may be conducive to a reformational view of the purpose of school education in which the contemporary search for spiritual connection is accounted for.

It was argued that Edwards' (worldviewish and ontological) understanding of the relation between God and creation has largely shaped his ideas in the areas of epistemology, anthropology and ethics. Edwards' understanding of creation as an act of God, whereby he purposefully communicates his glory, is complemented by his view of knowledge as the true perception of relations, of human beings as creation's consciousness, and of moral goodness as arising from true perception.

Three main applications were drawn from Edwards' philosophical thought to the question of the purpose of education. The first of these is that education should provide a context where learners may increasingly perceive the world as God-related, and therefore glory-filled. For this it is necessary that education will serve as a context in which sensory encounters are accompanied by dialogical guidance.

The second application is that education should guide learners to come to know the world as made for them, and themselves as made for it. They should be guided in knowing and enjoying the relation between themselves and the rest of creation. At the same time they should be guided to come to know and enjoy this relation as one which is intended for the communication of God's glory.

The third and final application is that education should promote sound morality as a response to true perception. Learners should be guided in perceiving human actions as responses to the God who has made humans to be the primary communicators of his glory. By learning to perceive human actions in this way, learners may themselves grow in moral goodness.

While not without its problems - some of which were dealt with in this article - Edwards' philosophical thought may be fruitful soil for the furthering of a reformational understanding of the purpose of education. This may be especially through providing ways of conceptualising various types of 'connection' in school education. These include, for example connection between knowledge and affection, connection between the learner and the world, and connection between knowledge and morality. Types of connection such as these are today pursued under the banner of 'spirituality'. Spirituality, or spiritual connection, should be comprehended within the framework of the relation between God and his creation.

\section{Acknowledgements Competing interests}

The author declares that she has no financial or personal relationships which may have inappropriately influenced her in writing this article.

\section{References}

Adams, E., 1991, 'Back to basics: Aesthetic experience', Children's Environments Quarterly 8(2), 19-29.

Anderson, J.A. \& Grice, J.W., 2014, 'Toward an integrated model of spirituality', Journa of Psychology and Christianity 33(1), 3-21.

Anderson, W.E., 1980, 'Note on the "Spider" papers', in W.E. Anderson (ed.), Scientific and philosophical writings, Works of Jonathan Edwards Online, vol. 6, 147-154 Yale University Press, New Haven, viewed 15 November 2015, from http:// edwards.yale.edu/archive?path=aHROcDovL2Vkd2FyZHMueWFsZS5IZHUvY2dp LWJpbi9uZXdwaGlsby9nZXRvYmplY3QucGw/Yy410jM6MS53amVv

Botha, P., 2006, 'Secular spirituality as virtue ethics: Actualising the Judaeo-Christian tradition today', in C. du Toit \& C. Mayson (eds.), Secular spirituality as a contextual critique of religion, pp. 75-94, University of South Africa, Pretoria.

Carr, D. \& Haldane, J., 2003, 'Introduction', in D. Carr \& J. Haldane (eds.), Spirituality, philosophy and education, pp. 1-6, Routledge Falmer, London.

Carrington, A., 2008, Moral beauty's divine center: Jonathan Edwards and the necessity of God in ethics, Statesmanship Thesis, Ashland University, Ashbrook, viewed 30 April 2015, from http://ashbrook.org/wp-content/uploads/2012/06/ 2007-Carrington-Moral-Beautys-Divine-Center-PDF.pdf

Choi, K.J., 2010, 'The role of perception in Edwards's moral thought: The nature of true virtue reconsidered', Journal of Religious Ethics 38(2), 269-296.

Culham, T., 2015, 'Reuniting virtue and knowledge', Journal of Philosophy of Education 49(2), 294-310, http://dx.doi.org/10.1111/1467-9752.12142

Dayton, E., 2015, 'On the spiritual dimension of education: Finding a common ground', Journal of Philosophy of Education 50(3), 432-447, http://dx.doi.org/10.1111/1467 9752.12149 
Du Plooy, J.L., Griessel, G.A.J. \& Oberholzer, M.O., 1982, Fundamental pedagogics for advanced students, HAUM Educational Publishers, Pretoria.

Edwards, J., 1959, Religious affections, vol. 2, ed. J.E. Smith, Yale University Press, New Haven.

Edwards, J., 1980a, 'The "Spider" letter', in W.E. Anderson (ed.), Scientific and Philosophical Writings vol. 6, 163-172.

Edwards, J., 1980b, 'Of atoms', in W.E. Anderson (ed.), Scientific and philosophical writings, vol. 6, 208-219.

Edwards, J., 1980c, 'Things to be considered and written fully about', in W.E. Anderson (ed.), Scientific and philosophical writings, vol. 6, 219-296.

Edwards, J., 1980d, 'Beauty of the world', in W.E. Anderson (ed.), Scientific and philosophical writings, vol. 6, 305-306.

Edwards, J., 1980e, 'The mind', in W.E. Anderson (ed.), Scientific and Philosophical Writings, vol. 6, 332-387.

Edwards, J., 1989, 'Two dissertations: vol. 1, 'Concerning the end for which God created the world' and vol. 2, 'On the nature of true virtue', in P. Ramsey (ed.) Ethical writings 8, 399-628, Yale University Press, New Haven.

Edwards, J., 1994, The 'Miscellanies': a-500, vol. 13, ed. H.S. Stout, Yale University Press, New Haven.

Edwards, J., 1998, Letters and personal writings, vol. 16, ed. G.S. Claghorn, Yale University Press, New Haven.

Edwards, J., 1999a, 'The pure in heart blessed', in M. Valeri (ed.), Sermons and discourses, 1730-1733, vol. 17, 57-86, Yale University Press, New Haven.

Edwards, J., 1999b, A divine and supernatural light', in M. Valeri (ed.), Sermons and discourses, 1730-1733, vol. 17, 408-426, Yale University Press, New Haven.

Edwards, J., 2000, The 'Miscellanies': 501-832, vol. 18, ed. A. Chamberlain, Yale University Press, New Haven.

Edwards, J., 2004, The 'Miscellanies': 1153-1360, vol. 23, ed. D.A. Sweeney, Yale University Press, New Haven.

Edwards, J., 2006, 'A strong rod broken and withered', in W.H. Kimnach (ed.), Sermons and discourses 1743-1758, -vol. 25, 312-329, Yale University Press, New Haven.

Edwards, J., [2015], 'Works of Jonathan Edwards Online', ed. by H.S. Stout, K.P. Minkema \& C.J.D. Maskell, viewed from Oct 2014 to Nov 2015, from http:// edwards.yale.edu

Fowler, S., 1987, Christian educational distinctives, PU for CHE, Potchefstroom.

Fowler, S., 1990, 'Schooling for the service of love', in H.W. van Brummelen \& J. van Dyk (eds.), Christian schooling: Education for freedom, 70-80, PU for CHE, Potchefstroom.

Fowler, S., 1991, A Christian voice among students and scholars, PU for $\mathrm{CHE}$ Potchefstroom.

Freeberg, B.A., 1999, 'The problem of divine ideas in eighteenth-century immaterialism: A comparative study of the philosophies of George Berkeley, Samuel Johnson, Arthur Collier, and Jonathan Edwards', PhD thesis, Faculty of Theology, Emory University, Atlanta.

Gibson, M.D., 2008, 'The beauty of the redemption of the world: The theological aesthetics of Maximus the Confessor and Jonathan Edwards', Harvard Theological Review 101(1), 45-76.

Goheen, M., 2002, 'Who turned out the light? Educational light in a dark world', Journal of Education and Christian belief 6(1), 45-47.

Jones, L., 2005, 'What does spirituality in education mean?', Journal of College and Character 6(7), Article 11

Kawano, Y., 2011, 'Spirituality and indigenous knowledges: Study of Kototama and decolonization in the school system', in N.N. Wane, E.J. Ritskes \& E.L. Manyimo (eds.), Spirituality, education and society: An integrated approach, pp. 97-110, Sense Publishers, Rotterdam.

Kourie, C., 2006, 'The "turn" to spirituality', Acta Theologica Supplementum 8, 19-38.

Lane. B.C., 2004, 'Jonathan Edwards on beauty, desire, and the sensory world', Theological Studies 65(1), 44-72.

Lee, S.H., 1988, The philosophical theology of Jonathan Edwards, Exp. ed., Princeton University Press, Princeton.

Louie, K.Y., 2007, 'The theological aesthetics of Jonathan Edwards', PhD Thesis, Faculty of Theology, University of Edinburgh, Edinburgh.

Marsden, G.M., 2003, Jonathan Edwards: A life, Yale University Press, New Haven.
McClymond, M.J. \& Reinke, T., 2012, 'The trinitarian shape of Jonathan Edwards' theology: An interview with Michael McClymond, Desiring God Foundation' Nov. 27, viewed 20 December 2014, from http://www.desiringgod.org/ Nov. 27, viewed 20 December 2014, from http://www.desiringgod.org/
interviews/the-trinitarian-shape-of-jonathan-edwards-theology-an-interviewinterviews/the-trinitarian-shape-of-
with-michael-mcclymond\#full-audio

Miller, P., 1949, Jonathan Edwards, William Sloane Associates, New York. (American Men of Letters Series)

Minkema, K.P., 2011, '"Informing of the child's understanding, influencing his heart, and directing its practice: Jonathan Edwards on education', Acta Theologica 31(2), 159-189.

Noll, M.A., 1995, 'Edwards, Jonathan', in A.E. McGrath (ed.), The Blackwell encyclopaedia of modern Christian thought, pp. 145-148, Blackwell., Malden.

Oliphint, K.S., 2003, 'Jonathan Edwards on apologetics: Reason and the noetic effects of $\sin ^{\prime}$, in D.G. Hart, S.M. Lucas \& S.J. Nichols (eds.), The legacy of Jonathan Edwards: American religion and the Evangelical tradition, pp. 133-146, Baker Academic, Grand Rapids.

Ortlund, D.C., 2014, Edwards on the Christian life: Alive to the beauty of God, Crossway, Wheaton.

Palmer, P.J., 1993, To know as we are known: Education as a spiritual journey, Harper San Francisco, San Francisco.

Plantinga, A., 2000, Warranted Christian belief, Oxford University Press, Oxford.

Postman, N., 1996, The end of education: Redefining the value of school, First Vintage Books, New York.

Rooy, S.H., 1965, The theology of missions in the Puritan tradition: A study of representative Puritans: Richard Sibbes, Richard Baxter, John Eliot, Cotton Mather, and Jonathan Edwards, Vrije Universiteit Amsterdam, Amsterdam.

Runner, H.E., 1970, The relation of the Bible to learning, 4th edn., Wedge Publishing Foundation, Toronto.

Rupp, G., 1969, 'The "idealism" of Jonathan Edwards', Harvard Theological Review 62(2), 209-226.

Sairsingh, K., 1986, 'Jonathan Edwards and the idea of divine glory: His foundational Trinitarianism and its ecclesial import', PhD thesis, Faculty of Theology, Harvard University, Cambridge.

Schultz, W., 2006, 'Jonathan Edwards's "End of creation": An exposition and defense', Journal of the Evangelical Theological Society 49(2), 247-271.

Spohn, W.C., 1981, 'Sovereign beauty: Jonathan Edwards and the nature of true virtue', Theological Studies 42(3), 394-421.

Stelting, D.E., 1998, 'Edwards as educator: His legacy of educational thought and practice', PhD thesis, Faculty of Education, University of Kansas, Kansas.

Sterling, S., 2001, Sustainable education: Re-visioning learning and change, Schumacher Briefings, Green Books for the Schumacher Society, Totnes.

Sterling, S., 2008, 'Education for sustainable development, policy and practice: A development education review', Issue 6, viewed on 11 Oct. 2015, from http:// www.developmenteducationreview.com/issue6-perspectives1

Strauss, D.F.M., 2012, 'Koers and the ideal of Christian scholarship', Koers 77(1), Article 29, http://dx.doi.org/10.4102/koers.v77i1.29

Troost, A., 1983, The Christian ethos: A philosophical survey, Patmos, Bloemfontein.

Van der Stelt, J.C., 2005, 'Faculty psychology and theology', in J.H. Kok (ed.), Ways of knowing in concert, pp. 45-59, Dordt College Press, Sioux Center.

Van der Walt, J.L., Wolhuter, C.C. \& Potgieter, F.J., 2008, 'Die intrinsieke verband tussen opvoeding en spiritualiteit', Koers 73(1), 1-14.

Vokey, D., 2003, 'Longing to connect: Spirituality and public schools', in D. Carr \& J. Haldane (eds.), Spirituality, philosophy and education, pp. 170-184, Routledge Falmer, London.

Vollenhoven, D.H. Th, 2005, Isagôgé philosophiae: Introduction to philosophy, transl. J.H. Kok, ed. J.H. Kok \& A. Tol, Dordt College Press, Sioux Center.

Wane, N.N. \& Ritskes, E.J., 2011, 'Introduction', in N.N. Wane, E.J. Ritskes \& E.L. Manyimo (eds.), Spirituality, education and society: An integrated approach, pp. xv-xxiii, Sense Publishers, Rotterdam.

Wolters, A.M., 2005, Creation regained: Biblical basics for a reformational worldview, 2nd edn., Eerdmans, Grand Rapids.

Wolterstorff, N.P., 2002, Educating for life: Reflections on Christian teaching and learning, Baker Academic, Grand Rapids.

Zakai, A., 2002, 'Jonathan Edwards and the language of nature: The re-enchantment of the world in the age of scientific reasoning', The Journal of Religious History 26(1), 15-41. 